

\title{
FT-IR, FT-Raman and ab-initio studies of 1,3-diphenyl thiourea
}

\author{
Chacko Yohannan Panickera,b,*, Hema Tresa Varghese ${ }^{b, c}$, \\ Abraham Georged and Puthenveettil Kandathil Varkey Thomas ${ }^{b}$
}

\author{
a Department of Physics, Thangal Kunju Musaliar College of Arts and Science, Kollam, Kerala, IN-691005, India \\ b Department of Physics, Mar Ivanios College, Trivandrum, Kerala, IN-695015, India \\ c Department of Physics, Fatima Mata National College, Kollam, Kerala, IN-691001, India \\ d Department of Chemistry, Mar Ivanios College, Trivandrum, Kerala, IN-695015, India
}

*Corresponding author at: Department of Physics, Thangal Kunju Musaliar College of Arts and Science, Kollam, Kerala, IN-691005, India. Tel.: +91.989.5370968; fax: +91.474.2711817. E-mail address: cyphyp@rediffmail.com (C.Y. Panicker).

\section{ARTICLE INFORMATION}

Received: 6 April 2010

Received in revised form: 8 August 2010

Accepted: 13 August 2010

Online: 30 September 2010

\section{KEYWORDS}

\section{FT-IR}

FT-Raman

Thiourea

Thiour

Hyperpolarizability

\section{ABSTRACT}

The FT-IR and FT-Raman spectra of 1,3-diphenyl thiourea were recorded and analyzed. The vibrational wavenumbers were examined theoretically with the aid of the Gaussian03 package of programs using the $H F / 6-311++G(d, p)$ and B3LYP/6-311++G(d,p) levels of theory. The data obtained from vibrational wavenumber calculations are used to assign vibrational bands obtained in IR and Raman spectroscopy of the studied molecule. The first hyperpolarizabililty, infrared intensities and Raman activities are reported. The calculated first hyperpolarizability is comparable with the reported values of similar derivatives and is an attractive object for future studies of non-linear optics. The geometrical parameters of the title compound are in agreement with the values of similar structures. The changes in the C-N bond lengths suggest an extended $\pi$-electron delocalization over the thiourea moiety which is responsible for the non-linearity of the molecule.

\section{Introduction}

Thiourea and substituted thioureas are versatile precursor units in the synthesis of many useful heterocyclic compounds [1]. Theoretical study of the $\mathrm{Hg}^{2+}$ recognition by 1,3diphenylthiourea has been reported [2]. The mechanism of enantioselective Michael addition of acetylacetone to a nitroolefin catalyzed by a thiourea based chiral bifunctional organocatalyst is investigated using density functional theory calculations [3]. Yang et al. [4] reported the structural and spectroscopic study of $N$-2-fluorobenzoyl- $N$ '-4-methoxyphenyl thiourea. Badawi reported the structural stability, C-N internal rotations and vibrational spectral analysis of non-planar phenylurea and phenylthiourea [5]. Metal organic coordination compounds as non linear optical (NLO) materials have attracted much more attention for their high NLO coefficients, stable physico-chemical properties and better mechanical intension. Many metal organic coordination complexes of thiourea materials with good NLO effects have been designed and synthesized [6-11]. Pfeffer et al. [12] reported the anion recognition using pre-orgranized thiourea functionalized polynorbornance receptors. There is currently great interest in the development of supramolecular systems that have the ability to bind and signal the presence of anions, as well as transporting such species across vesicle and cell membranes $[13,14]$. Molecules that possess functional groups such as amides, ureas and thioureas [15-17] have proven to be particularly effective in this regard as they are able to bind anions using directional hydrogen bonding interactions. Thiourea and substituted thioureas are especially important for their non linear optical properties. Hence the theoretical study of a symmetrically substituted aryl thiourea, 1,3-diphenyl thiourea, has been attempted.

\section{Experimental}

1,3-Diphenyl thiourea were prepared by reported method [18]. Briefly, 20 g sodium hydroxide $(0.5 \mathrm{~mol}), 30 \mathrm{~mL}$ carbon disulphide $(0.5 \mathrm{~mol}), 94 \mathrm{~mL}$ aniline $(1 \mathrm{~mol})$ and $5 \mathrm{~mL}$ ethyl alcohol were refluxed for 30 minutes in an RB flask. The solid thiourea separated is filtered at the pump, washed with water and ether and dried. White flake with a melting point of $153{ }^{\circ} \mathrm{C}$ was obtained. The purity was ascertained by TLC. The FT-IR (Figure 1) was recorded using a Perkin Elmer FTIR Spectrometer Spectrum RX1 with KBr pellets, number of scans 16, resolution $2 \mathrm{~cm}^{-1}$. The FT-Raman spectrum (Figure 2) was obtained on a Bruker Equinox 55/s spectrometer with FRA Raman socket, 106/s. For excitation of the spectrum the emission of Nd:YAG laser was used, excitation wavelength 1064 $\mathrm{nm}$, laser power $250 \mathrm{~mW}$, resolution $2 \mathrm{~cm}^{-1}$, number of scans 128 , measurement on solid sample.

\section{Computational details}

Calculations of the title compound were carried out with Gaussian03 software program [19] using the HF/6$311++G(d, p)$ and B3LYP $/ 6-311++G(d, p)$ basis sets to predict the molecular structure and vibrational wavenumbers and also with Becke's three parameter hybrid model using the LeeYang-Parr correlation functional (B3LYP) method. Molecular geometries were fully optimized by Berny's optimization algorithm using redundant internal coordinates. Harmonic vibrational wavenumbers were calculated using analytic second derivatives to confirm the convergence to minima on the potential surface. At the optimized structure (Figure 3) of the examined species, no imaginary wavenumber modes were obtained, proving that a true minimum on the potential surface 
was found. The DFT hybrid B3LYP functional tends to overestimate the fundamental modes; therefore scaling factors have to be used for obtaining a considerably better agreement with experimental data. Therefore, a scaling factor of 0.9613 and 0.8929 were uniformly applied to the DFT and HF calculated wavenumbers [20]. The observed disagreement between theory and experiment could be a consequence of the anharmonicity and of the general tendency of the quantum chemical methods to overestimate the force constants at the exact equilibrium geometry. Table 1 gives the calculated (DFT) geometrical parameters of the title compound.


Figure 1. FT-IR spectrum of 1,3-diphenyl thiourea (a) theoretical (b) experimental.

\section{Results and Discussion}

\subsection{IR and Raman spectra}

The observed IR, Raman bands with the relative intensities, scaled wavenumbers and assignments are given in Table 2. The assignments of the benzene ring vibrations of the title compound in Wilson notation [21] is made by referring the case of benzene derivatives with mono substitution as summarized by Roeges [22]. The NH stretching vibration [22] appears as a strong broad band in the region $3390 \pm 60 \mathrm{~cm}^{-1}$. In the present study, the $\mathrm{NH}$ stretching band is observed at 3217 $\mathrm{cm}^{-1}$ in the IR spectrum and at $3207 \mathrm{~cm}^{-1}$ in the Raman spectrum. The corresponding calculated values (DFT) are 3438 and $3432 \mathrm{~cm}^{-1}$. The $\mathrm{NH}$ stretching wavenumber is redshifted in the IR spectrum with a strong intensity from the computational wavenumber which indicates the weakening of the $\mathrm{N}-\mathrm{H}$ bond resulting in proton transfer to the neighbouring sulfur [23]. ElAsmy and Al-Hazmi [24] reported $v \mathrm{NH}$ in the region 3138-3323 $\mathrm{cm}^{-1}$. The $\mathrm{CNH}$ vibrations in which $\mathrm{N}$ and $\mathrm{H}$ atoms move in opposite directions of the carbon atom in the amide moiety appear at $1507,1494 \mathrm{~cm}^{-1}$ in the IR spectrum, $1517,1490 \mathrm{~cm}^{-1}$ in the Raman spectrum and at 1507, $1491 \mathrm{~cm}^{-1}$ theoretically (DFT) and the CNH vibrations in which $\mathrm{N}$ and $\mathrm{H}$ atoms move in the same direction of the carbon atom in the amide group appear at 1298, 1278 (IR), 1249 (Raman) and 1292, $1285 \mathrm{~cm}^{-1}$ (DFT) [25-27]. The NH rock in the plane is not seen in the IR spectrum but the DFT calculations give this mode at $1139 \mathrm{~cm}^{-1}$ [27]. The out-of-plane wagging [22] of $\mathrm{NH}$ is moderately active with a broad band in the region $790 \pm 70 \mathrm{~cm}^{-1}$ and the band at $858 \mathrm{~cm}^{-1}$ in the IR spectrum, $858 \mathrm{~cm}^{-1}$ in the Raman spectrum and $872,868 \mathrm{~cm}^{-1}$ (DFT) are assigned as this mode. El-Shahawy et al. [27] reported a value $710 \mathrm{~cm}^{-1}$ for this mode. Badawi reported [5] the NH vibrational modes at 3315, 1498, $1268 \mathrm{~cm}^{-}$ 1 in the IR spectrum, 3320, 1508, $1264 \mathrm{~cm}^{-1}$ in the Raman spectrum and at $3617,1502,1256 \mathrm{~cm}^{-1}$ theoretically. Panicker et al. [28] reported the $\mathrm{NH}$ bending modes at $1538,1220 \mathrm{~cm}^{-1}$ in the IR spectrum and at 1558, $1223 \mathrm{~cm}^{-1}$ theoretically (DFT).The C-N stretching vibration [22] coupled with $\delta \mathrm{NH}$, is moderately to strongly active in the region $1275 \pm 55 \mathrm{~cm}^{-1}$. ElShahawy et al. [27] observed a band at $1320 \mathrm{~cm}^{-1}$ in the IR spectrum as the $v \mathrm{CN}$ mode. Yang et al. [4] reported aromatic C$\mathrm{N}$ stretching band at $1359 \mathrm{~cm}^{-1}$. In the present case, the bands at $1326,1312 \mathrm{~cm}^{-1}$ in the IR spectrum and at $1345,1316 \mathrm{~cm}^{-1}$ in the Raman spectrum are assigned as this mode. The DFT calculations give the corresponding bands at 1318 and 1307 $\mathrm{cm}^{-1}$ which are not pure but contain significant contributions from other modes also.
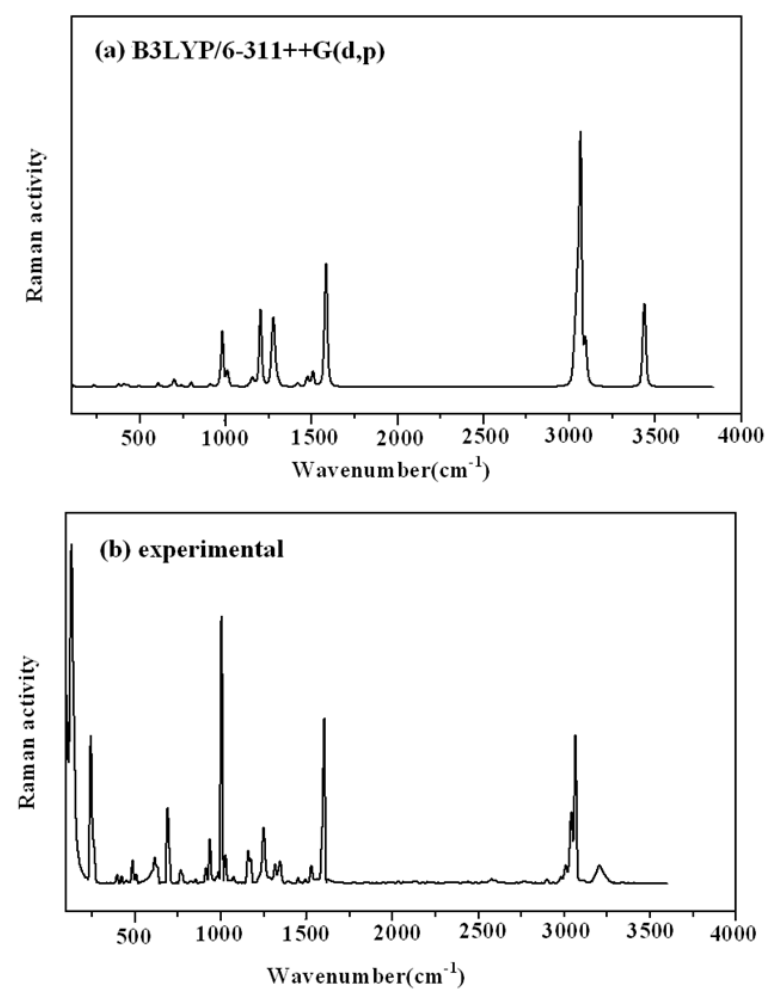

Figure 2. FT-Raman Spectrum of 1,3-diphenyl thiourea (a) theoretical (b) experimental.

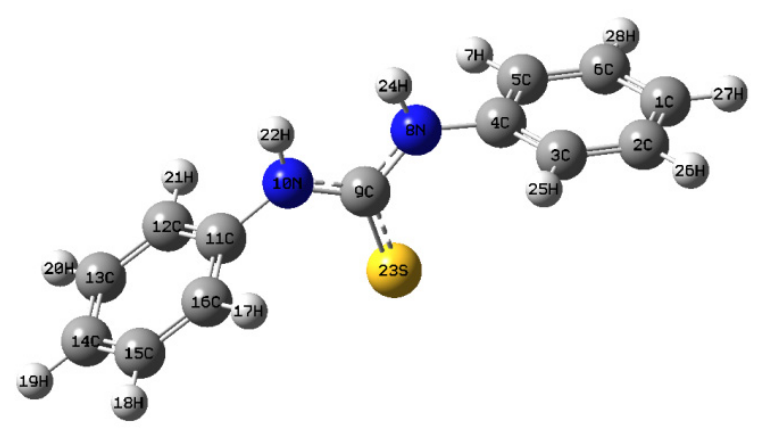

Figure 3. Optimized geometry of 1,3-diphenyl thiourea. 
Table 1. Geometrical parameters (DFT) of 1,3-diphenyl thiourea, atom labeling according to Figure 3.

\begin{tabular}{|c|c|c|c|c|c|}
\hline \multicolumn{2}{|c|}{ Bond lengths(§) } & \multicolumn{2}{|c|}{ Bond angles $\left({ }^{\circ}\right)$} & \multicolumn{2}{|c|}{ Dihedral angles( $\left.{ }^{\circ}\right)$} \\
\hline $\mathrm{C}_{1}-\mathrm{C}_{2}$ & 1.3949 & $\mathrm{C}_{2}-\mathrm{C}_{1}-\mathrm{C}_{6}$ & 119.4 & $\mathrm{C}_{6}-\mathrm{C}_{1}-\mathrm{C}_{2}-\mathrm{C}_{3}$ & -0.1 \\
\hline $\mathrm{C}_{1}-\mathrm{C}_{6}$ & 1.3928 & $\mathrm{C}_{1}-\mathrm{C}_{2}-\mathrm{C}_{3}$ & 120.8 & $\mathrm{C}_{2}-\mathrm{C}_{1}-\mathrm{C}_{6}-\mathrm{C}_{5}$ & -0.6 \\
\hline $\mathrm{C}_{2}-\mathrm{C}_{3}$ & 1.3915 & $\mathrm{C}_{2}-\mathrm{C}_{3}-\mathrm{C}_{4}$ & 119.7 & $\mathrm{C}_{1}-\mathrm{C}_{2}-\mathrm{C}_{3}-\mathrm{C}_{4}$ & 0.8 \\
\hline $\mathrm{C}_{3}-\mathrm{C}_{4}$ & 1.3976 & $\mathrm{C}_{3}-\mathrm{C}_{4}-\mathrm{C}_{5}$ & 119.6 & $\mathrm{C}_{2}-\mathrm{C}_{3}-\mathrm{C}_{4}-\mathrm{C}_{5}$ & -0.8 \\
\hline $\mathrm{C}_{4}-\mathrm{C}_{5}$ & 1.3981 & $\mathrm{C}_{3}-\mathrm{C}_{4}-\mathrm{N}_{8}$ & 122.1 & $\mathrm{C}_{2}-\mathrm{C}_{3}-\mathrm{C}_{4}-\mathrm{N}_{8}$ & -177.0 \\
\hline $\mathrm{C}_{4}-\mathrm{N}_{8}$ & 1.4188 & $\mathrm{C}_{5}-\mathrm{C}_{4}-\mathrm{N}_{8}$ & 118.2 & $\mathrm{C}_{3}-\mathrm{C}_{4}-\mathrm{C}_{5}-\mathrm{C}_{6}$ & 0.0 \\
\hline $\mathrm{C}_{5}-\mathrm{C}_{6}$ & 1.3928 & $\mathrm{C}_{4}-\mathrm{C}_{5}-\mathrm{C}_{6}$ & 120.3 & $\mathrm{~N}_{8}-\mathrm{C}_{4}-\mathrm{C}_{5}-\mathrm{C}_{6}$ & 176.4 \\
\hline $\mathrm{C}_{9}-\mathrm{N}_{8}$ & 1.3814 & $\mathrm{C}_{1}-\mathrm{C}_{6}-\mathrm{C}_{5}$ & 120.1 & $\mathrm{C}_{3}-\mathrm{C}_{4}-\mathrm{N}_{8}-\mathrm{C}_{9}$ & -47.3 \\
\hline $\mathrm{C}_{9}-\mathrm{N}_{10}$ & 1.3814 & $\mathrm{C}_{4}-\mathrm{N}_{8}-\mathrm{C}_{9}$ & 128.6 & $\mathrm{C}_{5}-\mathrm{C}_{4}-\mathrm{N}_{8}-\mathrm{C}_{9}$ & 136.4 \\
\hline $\mathrm{C}_{9}-\mathrm{S}_{23}$ & 1.6636 & $\mathrm{~N}_{8}-\mathrm{C}_{9}-\mathrm{N}_{10}$ & 110.1 & $\mathrm{C}_{4}-\mathrm{C}_{5}-\mathrm{C}_{6}-\mathrm{C}_{1}$ & 0.7 \\
\hline $\mathrm{C}_{11}-\mathrm{N}_{10}$ & 1.4188 & $\mathrm{~N}_{8}-\mathrm{C}_{9}-\mathrm{S}_{23}$ & 124.9 & $\mathrm{C}_{4}-\mathrm{N}_{8}-\mathrm{C}_{9}-\mathrm{N}_{10}$ & 173.0 \\
\hline $\mathrm{C}_{11}-\mathrm{C}_{12}$ & 1.3975 & $\mathrm{~N}_{10}-\mathrm{C}_{9}-\mathrm{S}_{23}$ & 124.9 & $\mathrm{C}_{4}-\mathrm{N}_{8}-\mathrm{C}_{9}-\mathrm{S}_{23}$ & -7.0 \\
\hline $\mathrm{C}_{11}-\mathrm{C}_{16}$ & 1.3981 & $\mathrm{C}_{9}-\mathrm{N}_{10}-\mathrm{C}_{11}$ & 128.6 & $\mathrm{~N}_{8}-\mathrm{C}_{9}-\mathrm{N}_{10}-\mathrm{C}_{11}$ & 173.1 \\
\hline $\mathrm{C}_{12}-\mathrm{C}_{13}$ & 1.3915 & $\mathrm{~N}_{10}-\mathrm{C}_{11}-\mathrm{C}_{12}$ & 122.1 & $\mathrm{~S}_{23}-\mathrm{C}_{9}-\mathrm{N}_{10}-\mathrm{C}_{11}$ & -6.9 \\
\hline $\mathrm{C}_{13}-\mathrm{C}_{14}$ & 1.3949 & $\mathrm{~N}_{10}-\mathrm{C}_{11}-\mathrm{C}_{16}$ & 118.2 & $\mathrm{C}_{9}-\mathrm{N}_{10}-\mathrm{C}_{11}-\mathrm{C}_{12}$ & -47.4 \\
\hline $\mathrm{C}_{14}-\mathrm{C}_{15}$ & 1.3928 & $\mathrm{C}_{12}-\mathrm{C}_{11}-\mathrm{C}_{16}$ & 119.6 & $\mathrm{C}_{9}-\mathrm{N}_{10}-\mathrm{C}_{11}-\mathrm{C}_{16}$ & 136.3 \\
\hline \multirow[t]{8}{*}{$\mathrm{C}_{15}-\mathrm{C}_{16}$} & 1.3928 & $\mathrm{C}_{11}-\mathrm{C}_{12}-\mathrm{C}_{13}$ & 119.7 & $\mathrm{~N}_{10}-\mathrm{C}_{11}-\mathrm{C}_{12}-\mathrm{C}_{13}$ & -177.0 \\
\hline & & $\mathrm{C}_{12}-\mathrm{C}_{13}-\mathrm{C}_{14}$ & 120.8 & $\mathrm{C}_{16}-\mathrm{C}_{11}-\mathrm{C}_{12}-\mathrm{C}_{13}$ & -0.8 \\
\hline & & $\mathrm{C}_{13}-\mathrm{C}_{14}-\mathrm{C}_{15}$ & 119.4 & $\mathrm{~N}_{10}-\mathrm{C}_{11}-\mathrm{C}_{16}-\mathrm{C}_{15}$ & 176.4 \\
\hline & & $\mathrm{C}_{14}-\mathrm{C}_{15}-\mathrm{C}_{16}$ & 120.1 & $\mathrm{C}_{12}-\mathrm{C}_{11}-\mathrm{C}_{16}-\mathrm{C}_{15}$ & 0.0 \\
\hline & & $\mathrm{C}_{11}-\mathrm{C}_{16}-\mathrm{C}_{15}$ & 120.3 & $\mathrm{C}_{11}-\mathrm{C}_{12}-\mathrm{C}_{13}-\mathrm{C}_{14}$ & 0.8 \\
\hline & & & & $\mathrm{C}_{12}-\mathrm{C}_{13}-\mathrm{C}_{14}-\mathrm{C}_{15}$ & -0.2 \\
\hline & & & & $\mathrm{C}_{13}-\mathrm{C}_{14}-\mathrm{C}_{15}-\mathrm{C}_{16}$ & -0.6 \\
\hline & & & & $\mathrm{C}_{14}-\mathrm{C}_{15}-\mathrm{C}_{16}-\mathrm{C}_{11}$ & 0.7 \\
\hline
\end{tabular}

The $\mathrm{C}=\mathrm{S}$ stretching bands $[22,25,29]$ are observed in the range $800 \pm 130 \mathrm{~cm}^{-1}$, usually with a moderate intensity. Since the $\mathrm{S}$ atom is less electronegative than the $\mathrm{O}$ atom, the $\mathrm{C}=\mathrm{S}$ group is not as polar as the $\mathrm{C}=0$ group and less prone to form bridges. The $\mathrm{C}=\mathrm{S}$ deformation bands are expected in the regions [22] $510 \pm 90$ and $420 \pm 100 \mathrm{~cm}^{-1}$. Nigam et al. [30] reported the $\mathrm{C}=\mathrm{S}$ stretching mode at 847 and $835 \mathrm{~cm}^{-1}$. For the title compound, the $\mathrm{C}=\mathrm{S}$ stretching mode is observed at $908 \mathrm{~cm}^{-1}$ in IR, $911 \mathrm{~cm}^{-1}$ in Raman and at $908 \mathrm{~cm}^{-1}$ theoretically (DFT).

The existence of one or more aromatic ring in a structure is normally readily determined from the $\mathrm{C}-\mathrm{H}$ and $\mathrm{C}=\mathrm{C}-\mathrm{C}$ related vibrations. The $\mathrm{C}-\mathrm{H}$ stretching occurs above $3000 \mathrm{~cm}^{-1}$ and is typically exhibited as a multiplicity of weak to moderate bands, compared with the aliphatic $\mathrm{C}-\mathrm{H}$ stretch [31]. For mono substituted benzenes, the $\mathrm{CH}$ stretching modes are expected in the region 3105-3000 $\mathrm{cm}^{-1}$ [22]. There are five $\mathrm{CH}$ stretching modes 20a, 20b, 2, 13, 7b for mono substituted benzenes. According to selection rules all five bands are allowed in the IR spectrum [26]. The calculated values are in the range 3097$3032 \mathrm{~cm}^{-1}$. The bands observed at 3113, 3062, 3042, $3020 \mathrm{~cm}^{-1}$ in the IR spectrum and at $3113,3068,3040,3010 \mathrm{~cm}^{-1}$ in the Raman spectrum were assigned as $\mathrm{vCH}$ modes of the benzene rings.

The benzene ring possesses six ring stretching vibrations, of which the four with the highest wavenumbers $(8 \mathrm{a}, 8 \mathrm{~b}, 19 \mathrm{a}$ and $19 \mathrm{~b}$, occurring respectively near $1600,1580,1490$ and $1440 \mathrm{~cm}^{-1}$ ) are good group vibrations. In the absence of ring conjugation, the band near $1580 \mathrm{~cm}^{-1}$ is usually weaker than that at $1600 \mathrm{~cm}^{-1}$. The fifth ring stretching vibration $\mathrm{vPh} 14$ is active near $1335 \pm 35 \mathrm{~cm}^{-1}$, a region which overlaps strongly with that of the $\mathrm{CH}$ in-plane deformation and the intensity is in general, low or medium high $[22,26]$. The sixth ring stretching vibration or ring breathing mode $\mathrm{UPh} 1$ appears as a weak band near $1000 \mathrm{~cm}^{-1}$ in mono substituted benzenes [22]. The bands observed at $1600,1589,1562,1475,1460,1434,1326,1312$ $\mathrm{cm}^{-1}$ in the IR spectrum and at $1602,1465,1345,1316 \mathrm{~cm}^{-1}$ in the Raman spectrum are assigned as $\mathrm{UPh}$ ring stretching modes. As seen from the Table 2, the DFT calculations give these modes in the range 1584- $1307 \mathrm{~cm}^{-1}$. These vibrations are expected in the region $1620-1300 \mathrm{~cm}^{-1}$ [22]. The frequency of the vibrational pair $8,19 \mathrm{a}$ in mono substituted benzenes is rather insensitive of substitution [26]. The frequency interval for vibration 19a is $1470-1515 \mathrm{~cm}^{-1}[26,32]$ and for all mono substituted benzene derivatives 19a have a band between 1477 and $1511 \mathrm{~cm}^{-1}$ in the IR spectrum. When derivatives have substituents of donor character, the frequency is found between 1493 and $1511 \mathrm{~cm}^{-1}$ and in this group of derivatives the band has higher intensity when a carbon atom is attached directly to the ring. For the title compound the ring breathing modes are assigned at $979,978 \mathrm{~cm}^{-1}$ theoretically. The strong band at $1004 \mathrm{~cm}^{-1}$ in the Raman spectrum is assigned with confidence to the characteristic ring breathing mode of the title compound. The ring breathing mode for mono substituted benzene is reported at $983 \mathrm{~cm}^{-1}$ by Panicker et al. [33] and at $1010 \mathrm{~cm}^{-1}$ in the Raman spectrum by Badawi et al. [5] for phenyl urea.

In mono substituted benzenes, there should be five $\mathrm{CH}$ inplane bending vibrations 3,9a, 9b, 15 and 18a. The mode 9a appears between 1170 and $1181 \mathrm{~cm}^{-1}$ in the spectra of all mono substituted benzene derivatives, mode 15 is found between 1060 and $1080 \mathrm{~cm}^{-1}$ and the intensity of 9a and 18a are the most intense in the IR spectrum [26,32]. The mode 3 is weak in general for both IR and Raman in the range 1253-1331 $\mathrm{cm}^{-1}$ [26]. In the present case the bands observed in the range 1003$1266 \mathrm{~cm}^{-1}$ in the IR spectrum, $1165-1024 \mathrm{~cm}^{-1}$ in the Raman spectrum and in the range $1009-1275 \mathrm{~cm}^{-1}$ (DFT) are assigned as $\delta \mathrm{CH}$ modes of the phenyl rings. Some modes are not pure, but contain significant contributions from other modes also. The in-plane $\mathrm{CH}$ vibrations are expected in the range 1015$1300 \mathrm{~cm}^{-1}$ for mono substituted benzenes [22].

The out-of-plane $\mathrm{CH}$ deformations $\gamma \mathrm{CH}$ of mono substituted benzene derivatives have the modes $5,10 \mathrm{a}, 11,17 \mathrm{a}$ and $17 \mathrm{~b}$ $[22,26]$. These modes are expected in the range $1000-700 \mathrm{~cm}^{-1}$ [22]. Generally, the $\mathrm{CH}$ out-of-plane deformations with the highest wavenumbers have a weaker intensity than those absorbing at lower wavenumbers. The stronger $\gamma \mathrm{CH}$ band occurring in the region $775 \pm 45 \mathrm{~cm}^{-1}(\gamma \mathrm{CH} 11$ or umbrella mode) tends to shift to lower (higher) wavenumbers with increasing electron donating (attracting) power of the substituent, but seems to be more sensitive to mechanical interaction effects. The lowest wavenumbers for this umbrella mode are found in the spectra of benzenes substituted with a saturated carbon or heavy atoms such as halogen, sulfur or phosphorus [26,34-36]. The bands at 938, 809, 789, 752, 698 $\mathrm{cm}^{-1}$ in the IR spectrum, 936, 765, $690 \mathrm{~cm}^{-1}$ in the Raman spectrum and the calculated values (DFT) in the range 945-699 $\mathrm{cm}^{-1}$ are assigned as the out-of-plane $\mathrm{CH}$ modes of the phenyl rings. The out-of-plane $\mathrm{CH}$ deformation $\gamma \mathrm{CH} 11$ at $698 \mathrm{~cm}^{-1}$ and the out-of-plane ring deformation $\gamma \mathrm{Ph} 4$ at $655,632 \mathrm{~cm}^{-1}$ in the IR spectrum form a pair of strong bands characteristic of mono substituted benzene derivatives, which find support from computational results $[22,36]$. 
Table 2. Calculated (scaled) vibrational wavenumbers, measured infrared and Raman band positions and assignments for 1,3-diphenyl thiourea* .

\begin{tabular}{|c|c|c|c|c|c|c|c|c|}
\hline \multicolumn{3}{|c|}{ HF/6-311++G(d,p) } & \multicolumn{3}{|c|}{ B3LYP/6-311++G(d,p) } & \multirow{2}{*}{$\begin{array}{l}\text { IR } \\
v\left(\mathrm{~cm}^{-1}\right)\end{array}$} & \multirow{2}{*}{$\begin{array}{l}\text { Raman } \\
v\left(\mathrm{~cm}^{-1}\right)\end{array}$} & \multirow{2}{*}{ Assignments } \\
\hline$v\left(\mathrm{~cm}^{-1}\right)$ & IR intensity & Raman activity & $v\left(\mathrm{~cm}^{-1}\right)$ & IR intensity & Raman activity & & & \\
\hline 3437 & 54.13 & 207.48 & 3438 & 18.55 & 273.43 & $3217 \mathrm{sbr}$ & $3207 \mathrm{sbr}$ & $v \mathrm{NH}$ \\
\hline 3429 & 8.21 & 0.22 & 3432 & 10.57 & 28.07 & & & $v \mathrm{NH}$ \\
\hline 3009 & 0.21 & 521.89 & 3097 & 0.26 & 90.23 & $3113 \mathrm{sh}$ & $3113 w$ & vCH 20a \\
\hline 3009 & 7.66 & 27.09 & 3097 & 4.36 & 21.65 & & & vCH 20a \\
\hline 3005 & 54.10 & 0.71 & 3066 & 0.07 & 516.99 & & $3068 \mathrm{~s}$ & vCH 20b \\
\hline 3005 & 0.00 & 0.04 & 3066 & 56.25 & 63.04 & $3062 \mathrm{sh}$ & & $v \mathrm{CH} 20 \mathrm{~b}$ \\
\hline 2997 & 5.70 & 103.11 & 3054 & 25.16 & 104.16 & & & $v \mathrm{CH} 2$ \\
\hline 2996 & 70.71 & 13.68 & 3054 & 28.19 & 87.46 & & & vCH 2 \\
\hline 2987 & 14.18 & 26.86 & 3044 & 0.27 & 118.88 & & $3040 \mathrm{~s}$ & vCH 13 \\
\hline 2987 & 0.79 & 198.91 & 3044 & 1.17 & 72.08 & $3042 \mathrm{~m}$ & & vCH 13 \\
\hline 2976 & 0.02 & 70.85 & 3032 & 8.47 & 42.84 & & & $v \mathrm{CH} 7 \mathrm{~b}$ \\
\hline 2976 & 0.32 & 6.60 & 3032 & 12.46 & 41.17 & $3020 w$ & $3010 \mathrm{w}$ & $v \mathrm{CH} 7 \mathrm{~b}$ \\
\hline 1605 & 0.01 & 69.97 & 1584 & 0.68 & 378.46 & $1600 \mathrm{~s}$ & 1602 vs & $v \mathrm{Ph} 8 \mathrm{a}$ \\
\hline 1601 & 37.17 & 3.50 & 1583 & 27.14 & 4.37 & $1589 \mathrm{~s}$ & & vPh 8a \\
\hline 1584 & 4.32 & 3.81 & 1578 & 1.36 & 7.12 & & & $v \mathrm{Ph} 8 \mathrm{~b}$ \\
\hline 1583 & 0.00 & 19.94 & 1574 & 69.67 & 6.01 & $1562 \mathrm{sbr}$ & & $v \mathrm{Ph} 8 \mathrm{~b}$ \\
\hline 1529 & 0.75 & 5.15 & 1507 & 427.45 & 44.96 & $1507 \mathrm{~m}$ & $1517 \mathrm{~m}$ & $\delta \mathrm{NH}$ \\
\hline 1514 & 694.37 & 14.95 & 1491 & 427.45 & 0.74 & $1494 \mathrm{~s}$ & $1490 \mathrm{w}$ & $\delta \mathrm{NH}$ \\
\hline 1478 & 0.08 & 1.81 & 1475 & 0.41 & 38.50 & $1475 \mathrm{w}$ & & vPh 19a \\
\hline 1478 & 3.31 & 2.65 & 1474 & 172.86 & 1.01 & $1460 \mathrm{~s}$ & $1465 \mathrm{w}$ & $v \mathrm{Ph} 19 \mathrm{a}$ \\
\hline 1431 & 10.43 & 0.19 & 1426 & 2.85 & 8.28 & $1434 \mathrm{sh}$ & & $v \mathrm{Ph} 19 \mathrm{~b}$ \\
\hline 1431 & 0.00 & 2.05 & 1416 & 152.88 & 7.10 & & & $v \mathrm{Ph} 19 \mathrm{~b}$ \\
\hline 1300 & 0.41 & 0.01 & 1318 & 48.36 & 2.73 & $1326 \mathrm{~s}$ & $1345 \mathrm{~m}$ & $v C N, v \mathrm{Ph} 14$ \\
\hline 1299 & 0.00 & 1.29 & 1307 & 2.35 & 4.15 & $1312 \mathrm{~m}$ & $1316 \mathrm{w}$ & $v C N, v \mathrm{Ph} 14$ \\
\hline 1283 & 286.93 & 5.00 & 1292 & 26.02 & 47.13 & $1298 \mathrm{~m}$ & & $\delta \mathrm{NH}$ \\
\hline 1234 & 405.06 & 2.81 & 1285 & 243.79 & 0.76 & $1278 \mathrm{~m}$ & $1249 \mathrm{~s}$ & $\delta \mathrm{NH}$ \\
\hline 1224 & 97.96 & 32.87 & 1275 & 106.34 & 240.58 & $1266 \mathrm{~m}$ & & $\delta \mathrm{CH} 3$ \\
\hline 1181 & 3.91 & 0.55 & 1216 & 368.10 & 0.35 & $1218 w$ & & 8CH 3 \\
\hline 1181 & 0.00 & 0.77 & 1202 & 75.85 & 198.71 & & & $\delta \mathrm{CH} 9 \mathrm{a}$ \\
\hline 1169 & 28.65 & 0.05 & 1161 & 75.94 & 0.28 & 1168 w & $1165 \mathrm{~m}$ & $\rho \mathrm{CH} 9 \mathrm{a}$ \\
\hline 1145 & 1.62 & 5.29 & 1159 & 0.52 & 20.29 & & $1159 \mathrm{~m}$ & $\rho \mathrm{CH} 9 \mathrm{~b}$ \\
\hline 1144 & 6.15 & 0.83 & 1156 & 51.81 & 9.34 & 1156 w & & $\delta \mathrm{CH} 9 \mathrm{~b}$ \\
\hline 1071 & 14.49 & 0.00 & 1139 & 0.34 & 6.78 & & & $\rho \mathrm{NH}$ \\
\hline 1071 & 0.00 & 4.42 & 1139 & 1.01 & 4.21 & & & $\rho \mathrm{NH}$ \\
\hline 1039 & 1.96 & 0.46 & 1065 & 10.56 & 0.38 & $1070 \mathrm{~s}$ & $1070 \mathrm{w}$ & $v \mathrm{CX}(\mathrm{X}) 7 \mathrm{a}, \delta \mathrm{CH} 15$ \\
\hline 1039 & 0.00 & 0.36 & 1063 & 0.70 & 1.60 & & & $v \mathrm{CX}(\mathrm{X}) 7 \mathrm{a}, \delta \mathrm{CH} 15$ \\
\hline 1001 & 0.73 & 11.18 & 1011 & 0.46 & 41.57 & $1018 \mathrm{~m}$ & $1024 \mathrm{w}$ & $\delta \mathrm{CH} 18 \mathrm{a}$ \\
\hline 998 & 13.77 & 0.27 & 1009 & 10.19 & 1.01 & $1003 \mathrm{w}$ & & $\delta \mathrm{CH} 18 \mathrm{a}$ \\
\hline 992 & 0.00 & 0.43 & 979 & 0.26 & 156.74 & & 1004 vs & vPh 1 \\
\hline 992 & 0.01 & 0.43 & 978 & 0.06 & 2.62 & $975 \mathrm{w}$ & & $v \mathrm{Ph} 1$ \\
\hline 975 & 0.55 & 0.00 & 945 & 0.01 & 0.12 & & & $\gamma \mathrm{CH} 5$ \\
\hline 975 & 0.00 & 0.00 & 945 & 0.19 & 0.14 & $938 \mathrm{~s}$ & & $\gamma \mathrm{CH} 5$ \\
\hline 972. & 0.62 & 76.75 & 920 & 0.53 & 1.78 & & $936 \mathrm{w}$ & $\gamma \mathrm{CH} 17 \mathrm{a}$ \\
\hline 970 & 4.41 & 0.20 & 920 & 0.16 & 0.34 & & & $\gamma \mathrm{CH} 17 \mathrm{a}$ \\
\hline 931 & 4.33 & 0.06 & 908 & 6.07 & 9.76 & $908 \mathrm{w}$ & $911 \mathrm{w}$ & vCS \\
\hline 930 & 1.64 & 34.93 & 872 & 4.01 & 0.41 & & & $\omega \mathrm{NH}$ \\
\hline 898 & 10.46 & 24.68 & 868 & 0.22 & 0.40 & $858 \mathrm{w}$ & $858 \mathrm{w}$ & $\omega \mathrm{NH}$ \\
\hline 839 & 2.26 & 0.71 & 800 & 0.73 & 0.56 & $809 w$ & & $\gamma \mathrm{CH} 17 \mathrm{~b}$ \\
\hline 838 & 0.00 & 0.12 & 798 & 1.19 & 12.03 & & & $\gamma \mathrm{CH} 17 \mathrm{~b}$ \\
\hline 807 & 10.40 & 1.43 & 792 & 3.90 & 1.21 & $789 \mathrm{~s}$ & & $\gamma \mathrm{CH} 10 \mathrm{a}$ \\
\hline 759 & 26.25 & 13.32 & 747 & 20.68 & 1.21 & $752 \mathrm{~s}$ & $765 \mathrm{w}$ & $\gamma \mathrm{CH} 10 \mathrm{a}$ \\
\hline 756 & 12.66 & 2.89 & 742 & 13.22 & 4.86 & & & $\gamma \mathrm{CH} 11$ \\
\hline 684 & 7.79 & 0.20 & 699 & 64.56 & 27.49 & $698 \mathrm{~s}$ & $690 \mathrm{~s}$ & $\gamma \mathrm{CH} 11$ \\
\hline 683 & 145.77 & 6.87 & 691 & 70.30 & 0.66 & $690 \mathrm{~s}$ & & $\delta \mathrm{Ph}(\mathrm{X}) 12$ \\
\hline 669 & 10.40 & 14.71 & 673 & 29.56 & 3.08 & & & $\delta \mathrm{Ph}(\mathrm{X}) 12$ \\
\hline 637 & 0.51 & 0.00 & 667 & 10.06 & 0.12 & $655 \mathrm{~s}$ & & $\gamma \mathrm{Ph} 4$ \\
\hline 635 & 14.26 & 0.37 & 629 & 6.45 & 2.33 & $632 \mathrm{~s}$ & $628 \mathrm{w}$ & $\gamma \mathrm{Ph} 4$ \\
\hline 619 & 16.00 & 3.96 & 608 & 2.50 & 4.14 & $611 \mathrm{~m}$ & $615 \mathrm{~m}$ & $\delta \mathrm{CS}$ \\
\hline 604 & 0.00 & 8.57 & 607 & 0.74 & 8.56 & $599 \mathrm{w}$ & & $\delta \mathrm{Ph} 6 \mathrm{~b}$ \\
\hline 602 & 1.27 & 1.10 & 571 & 2.86 & 1.60 & $563 \mathrm{w}$ & & $\delta \mathrm{Ph} 6 \mathrm{~b}$ \\
\hline 490 & 9.63 & 2.85 & 497 & 5.95 & 3.54 & $505 \mathrm{w}$ & $506 \mathrm{w}$ & $\gamma \mathrm{CS}$ \\
\hline 476 & 13.50 & 2.01 & 488 & 0.75 & 1.74 & $486 \mathrm{~s}$ & $485 w$ & $\gamma \mathrm{Ph}(\mathrm{X}) 16 \mathrm{~b}$ \\
\hline 436 & 0.01 & 0.23 & 478 & 4.96 & 0.02 & & & $\gamma \mathrm{Ph}(\mathrm{X}) 16 \mathrm{~b}$ \\
\hline 425 & 102.84 & 0.30 & 433 & 216.39 & 5.80 & $439 w$ & $440 \mathrm{w}$ & $\rho \mathrm{CSN}$ \\
\hline 410 & 0.00 & 0.02 & 415 & 74.15 & 6.74 & & $419 w$ & $\gamma \mathrm{Ph}(\mathrm{X})$ \\
\hline 403 & 39.72 & 0.16 & 402 & 0.07 & 5.98 & & & $\gamma \mathrm{Ph}(\mathrm{X})$ \\
\hline 400 & 0.00 & 0.17 & 401 & 0.15 & 0.42 & & $398 \mathrm{w}$ & $\delta \mathrm{Ph}(\mathrm{X}) 6 \mathrm{a}$ \\
\hline 380 & 1.73 & 0.29 & 375 & 2.79 & 8.72 & & & $\delta \mathrm{Ph}(\mathrm{X}) 6 \mathrm{a}$ \\
\hline 238 & 0.83 & 3.53 & 321 & 0.32 & 0.21 & & & $\delta \mathrm{CX}(\mathrm{X}) 18 \mathrm{~b}$ \\
\hline 222 & 4.407 & 2.09 & 235 & 0.75 & 7.78 & & $242 \mathrm{~s}$ & $\delta \mathrm{CX}(\mathrm{X}) 18 \mathrm{~b}$ \\
\hline 218 & 0.35 & 4.50 & 228 & 2.54 & 0.77 & & & $\rho C(=S) N H$ \\
\hline 175 & 0.00 & 0.02 & 204 & 1.03 & 0.79 & & & $\rho \operatorname{CSN}$ \\
\hline 103 & 4.98 & 4.25 & 130 & 8.04 & 1.88 & & $129 \mathrm{~s}$ & $\gamma \mathrm{CX}(\mathrm{X}) 10 \mathrm{~b}$ \\
\hline 71 & 0.00 & 0.75 & 106 & 0.03 & 8.58 & & & $\gamma \mathrm{CX}(\mathrm{X}) 10 \mathrm{~b}$ \\
\hline 52 & 0.84 & 1.94 & 54 & 0.31 & 4.35 & & & $\mathrm{tPh}$ \\
\hline 27 & 2.95 & 0.15 & 40 & 1.80 & 4.71 & & & $\mathrm{tPh}$ \\
\hline 20 & 3.68 & 8.51 & 32 & 0.05 & 12.78 & & & tCSN \\
\hline 7 & 0.00 & 1.26 & 28 & 0.13 & 2.00 & & & $\mathrm{tCSN}$ \\
\hline
\end{tabular}

* $v$-stretching; $\delta$-in-plane deformation; $\gamma$-out-of-plane deformation; $\rho$-rocking; $\omega$-wagging; t-torsion; X-substituent sensitive; Ph-phenyl ring. 

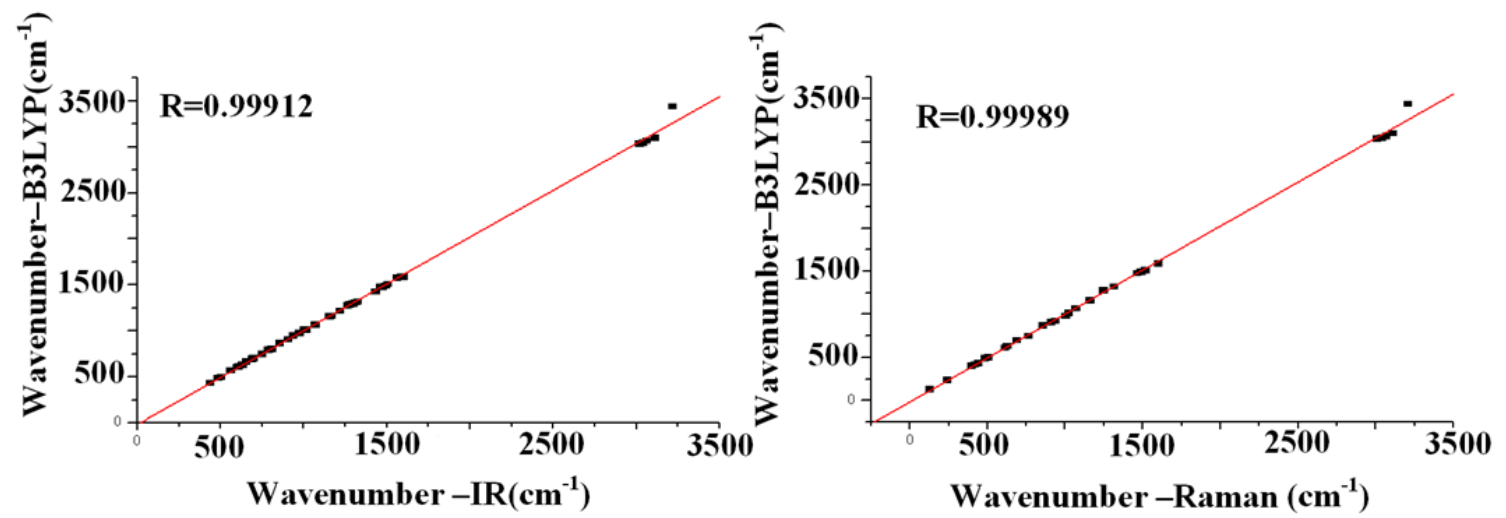

Figure 4. Correlation graph between experimental and calculated wavenumbers.

In mono substituted benzenes, six modes of vibrations are substituent sensitive, which means that their wavenumbers shift systematically with mass or inductive or mesomeric effects of the substituent. The highest substituent sensitive mode $v C X(X)$ mode $7 \mathrm{a}$ appears in the region $1195 \pm 90 \mathrm{~cm}^{-1}$ for mono substituted benzenes [22,37]. The band corresponding to mode $7 \mathrm{a}$ is generally strong both in IR and Raman spectra. For the title compound the $\mathrm{UCX}(\mathrm{X})$ modes are observed in the IR spectrum at $1070 \mathrm{~cm}^{-1}$, and at $1070 \mathrm{~cm}^{-1}$ in Raman spectrum. The DFT calculations give values at $1065,1063 \mathrm{~cm}^{-1}$. Moreover, the other substituent sensitive modes are identified (Table 2). The correlation graph between experimental and calculated wavenumbers is shown in Figure 4. The IR bands in the 1729$2770 \mathrm{~cm}^{-1}$ region and their large broadening support the intramolecular hydrogen bonding [33].

\subsection{Geometrical parameters and first hyperpolarizability}

The C-C bond length in the phenyl rings lie between 1.3915 and $1.3981 \AA$ A Here for the title compound, benzene is a regular hexagon with bond lengths somewhere between the normal values for a single $(1.54 \AA)$ and a double $(1.33 \AA)$ bond [38]. The $\mathrm{C}_{11}-\mathrm{C}_{12}, \mathrm{C}_{11}-\mathrm{C}_{16}, \mathrm{C}_{4}-\mathrm{C}_{3}$ and $\mathrm{C}_{4}-\mathrm{C}_{5}$ bond lengths are longer than all the other $\mathrm{C}-\mathrm{C}$ bonds. This is due to the presence of the electronegative nitrogen atom, which can pull electrons from the ring elongating the bond. Since the molecule is symmetric, all the structural parameters also exhibit the symmetry on both sides. Both the N-H bonds are oriented away from the C-S bond so as to reduce the repulsive forces. Another interesting feature of the molecule is that, the planes of both the benzene rings are perpendicular to each other. Yang et al. [4] reported bond lengths $\mathrm{N}_{10}-\mathrm{C}_{9}=1.38, \mathrm{~N}_{8}-\mathrm{C}_{9}=1.404 \AA$, whereas in the present case, the corresponding value is $1.3814 \AA$ and shorter than C-N single bond of $1.4725 \AA$. The partial double bond character of the structure is presumed as a result of the intra-molecular $\mathrm{H}$ bond "locking" the molecule into a planar six-numbered ring structure.

The C-S bond length in the present study $1.6636 \AA$ lies between the values of C-S single and double bonds. The $\mathrm{C}_{4}-\mathrm{N}_{8}$ bond length for the title compound is $1.4188 \AA$, formally a single bond, which is remarkably shortened. The reported values of the bond lengths are, $\mathrm{C}_{9}-\mathrm{S}_{23}=1.663$ [4] and $\mathrm{C}_{4}-\mathrm{N}_{8}$ $=1.421 \AA \AA$ [4]. Dilovic et al. [39] reported the bond lengths, $\mathrm{C}_{9}-$ $\mathrm{S}_{23}=1.6792, \quad \mathrm{C}_{9}-\mathrm{N}_{8}=1.3422, \quad \mathrm{C}_{9}-\mathrm{N}_{10}=1.3462 . \mathrm{C}_{4}-\mathrm{N}_{8}=1.4122 \AA$, bond angles $\mathrm{C}_{11}-\mathrm{N}_{10}-\mathrm{C}_{9}=129.7, \mathrm{~N}_{10}-\mathrm{C}_{9}-\mathrm{N}_{8}=114.3, \mathrm{~N}_{10}-\mathrm{C}_{9}-\mathrm{S}_{23}=$ 116.8, $\mathrm{S}_{23}-\mathrm{C}_{9}-\mathrm{N}_{8}=128.8, \mathrm{C}_{9}-\mathrm{N}_{8}-\mathrm{C}_{4}=130.7, \mathrm{~N}_{8}-\mathrm{C}_{4}-\mathrm{C}_{5}=124.7^{\circ}$ and the dihedral angles $\mathrm{C}_{11}-\mathrm{N}_{10}-\mathrm{C}_{9}-\mathrm{S}_{23}=-173.4, \mathrm{C}_{4}-\mathrm{N}_{8}-\mathrm{C}_{9}-\mathrm{S}_{23}=-1.8, \mathrm{C}_{4}-$ $\mathrm{N}_{8}-\mathrm{C}_{9}-\mathrm{N}_{10}=179.1^{\circ}$, which are in agreement with the corresponding values for the title compound. Ramnathan et al. [40] reported $\mathrm{C}_{9}-\mathrm{S}_{23}=1.7073, \mathrm{C} 4-\mathrm{N} 8=1.445, \mathrm{C}_{11}-\mathrm{N}_{10}=1.4375 \AA$, $\mathrm{C}_{9-\mathrm{N}_{8}-}$ $\mathrm{C}_{4}=127.8^{\circ}, \mathrm{C}_{9}-\mathrm{N}_{10}-\mathrm{C}_{11}=125.5^{\circ}, \mathrm{N}_{8}-\mathrm{C}_{9}-\mathrm{N}_{10}=117.3^{\circ}, \mathrm{N}_{8}-\mathrm{C}_{9}-\mathrm{S}_{23}=$ $120.4^{\circ}, \mathrm{N}_{10}-\mathrm{C}_{9}-\mathrm{S}_{23}=122.2^{\circ}$, whereas the corresponding values in the present case are, $1.6636,1.4188,1.4188 \AA \AA, 128.6,128.6$, $110.1,124.9$, and $124.9^{\circ}$.

The first hyperpolarizability $\left(\beta_{0}\right)$ of this novel molecular system is calculated using B3LYP/6-311++G(d,p) method, based on the finite field approach. In the presence of an applied electric field, the energy of a system is a function of the electric field. First hyperpolarizability is a third rank tensor that can be described by a $3 \times 3 \times 3$ matrix. The 27 components of the $3 \mathrm{D}$ matrix can be reduced to 10 components due to the Kleinman symmetry [41]. The components of $\beta$ are defined as the coefficients in the Taylor series expansion of the energy in the external electric field. When the electric field is weak and homogeneous, this expansion becomes

$$
E=E_{0}-\sum_{i} \mu_{i} F^{i}-\frac{1}{2} \sum_{i j} \alpha_{i j} F^{i} F^{j}-\frac{1}{6} \sum_{i j k} \beta_{i j k} F^{i} F^{j} F^{k}-\frac{1}{24} \sum_{i j k l} \gamma_{j i k l} F^{i} F^{j} F^{k} F^{l}+\ldots
$$

where, $E_{0}$ is the energy of the unperturbed molecule, $F^{i}$ is the field at the origin, $\mu_{i}, \alpha_{i j}, \beta_{i j k}$ and $\gamma_{i j k l}$ are the components of dipole moment, polarizability, the first hyper polarizabilities, and second hyperpolarizabilities, respectively. The calculated first hyperpolarizability of the title compound is $1.86 \times 10^{-30} \mathrm{esu}$, which is 14.36 times that of urea $\left(0.13 \times 10^{-30} \mathrm{esu}\right)$ [42]. The C-N distances in the calculated molecular structure vary from 1.3814 to $1.4188 \AA$ which are intermediate between those of a $\mathrm{C}-\mathrm{N}$ single bond $(1.48 \AA)$ and a $\mathrm{C}=\mathrm{N}$ double bond $(1.28 \AA)$. Therefore, the calculated data suggest an extended $\pi$-electron delocalization over the thiourea moiety $[42,43]$ which is responsible for the nonlinearity of the molecule. We conclude that the title compound is an attractive molecule in future for non linear optical applications.

\section{Conclusion}

The FT-IR and FT-Raman spectra of 1,3-diphenyl thiourea were recorded and analyzed. The wavenumbers are calculated theoretically using Gaussian03 software package. The normal modes of the phenyl ring are assigned by comparing experimental wavenumbers and theoretically calculated wavenumbers. The NH stretching wavenumber is redshifted in the IR spectrum with a strong intensity from the computational wavenumber which indicates the weakening of the $\mathrm{N}-\mathrm{H}$ bond resulting in proton transfer to the neighboring sulfur atom. The small differences between experimental and calculated vibrational modes are observed. It must be due to the fact that hydrogen bond vibrations present in the crystal lead to strong perturbation of the infrared wavenumbers and intensities of many other modes. Furthermore, we state that experimental results belong to solid phase and theoretical calculations belong to gaseous phase. The first hyperpolarizabililty, infrared 
intensities and Raman activities are reported. The calculated first hyperpolarizability is comparable with the reported values of similar derivatives and is an attractive object for future studies of non-linear optics.

\section{References}

[1]. Katrizky, A.R, Advances in Heterocyclic Chemistry, Academic Press, New York, 1983.

[2]. Castro, M.; Cruz, J.; Otazo-Sanchez, E.; Perez-Marın, L. J. Phys. Chem. A 2003, 107, 9000-9007.

[3]. Hamza, A.; Schubert, G.; Soos, T.; Papai, I. J. Am. Chem. Soc. 2006, 128, 13151-13160

[4]. Yang, W.; Zhou, W.; Zhang, Z. J. Mol. Struct. 2007, 828, 46-53.

[5]. Badawi, H. M. Spectrochim. Acta 2009, 72A, 523-527.

[6]. Zhang, N.; Jiang, M. H.; Yuan, D. R.; Xu, D.; Tao, X. T.; Shao, Z. S. J. Cryst. Growth 1990, 102, 580-584.

[7]. Ushasree, P. M.; Muralidharan, R.; Jayavel, R.; Ramasamy, P. J. Cryst. Growth 2000, 218, 365-371.

[8]. Qussaid, M.; Becker, P.; Nedelec, C. C. Phys. Stat. Sol.(b) 1998, 207, 499-507.

[9]. Marcy, H.O.; Warren, L. F.; Webb, M. S.; Ebbers, C. A.; Velsko, S. P.; Kennedy, G. C.; Catella, G. C. Appl. Opt. 1992, 31, 5051-5060.

[10]. Selvaraju, K.; Valluvan, R.; Kumararaman, S. Mater. Lett. 2006, 60, 3130-3132.

[11]. Selvaraju, K.; Valluvan, R.; Kumararaman, S. Mater. Lett. 2007, 61, 751-753.

[12]. Pfeffer, F. M.; Gunnlaugsson, T.; Jensen, P.; Kruger, P. E. Org. Lett. 2005, 7, 5357-5360.

[13]. Beer, P.D.; Gale, P. A. Angew. Chem. Int. Ed. 2001, 40, 486-516.

[14]. Koulov, A. V.; Mahoney, J. M.; Smith, B. D. Org. Biomol. Chem. 2003, 1, 27-29.

[15]. Gunnlaugsson, T.; Ali, H. D. P.; Glynn, M.; Kruger, P. E.; Hussey, G. M.; Pfeffer, F. M.; dos Santos, C. M. G.; Tierney, J. J. Fluoresc. 2005, 15, 287 299.

[16]. Kim, S. K.; Singh, N. J.; Kim, S. J.; Swamy, K. M. K.; Kim, S. H.; Lee, K. H.; Kim, K. S.;. Yoon, J. Tetrahedron 2005, 61, 4545-4550.

[17]. Hay, B. P.; Firman, T. K.; Moyer, B. A. J. Am. Chem. Soc. 2005, 127, 1810-1819.

[18]. Vogel, A.I. A Text Book of Practical Organic Chemistry; Longmans: London, 1954, p 614.

[19]. Frisch, M. J.; Trucks, G. W.; Schlegel, H. B.; Scuseria, G. E.; Robb, M. A.; Cheeseman, J. R.; Montgomery, Jr., J. A.; Vreven, T.; Kudin, K. N.; Burant, J. C.; Millam, J. M.; Iyengar, S. S.; Tomasi, J.; Barone, V.; Mennucci, B.; Cossi, M.; Scalmani, G.; Rega, N.; Petersson, G. A.; Nakatsuji, H.; Hada, M.; Ehara, M.; Toyota, K.; Fukuda, R.; Hasegawa, J.; Ishida, M.; Nakajima, T.; Honda, Y.; Kitao, O.; Nakai, H.; Klene, M.; Li, X.; Knox, J. E.; Hratchian, H. P.; Cross, J. B.; Adamo, C.; Jaramillo, J.; Gomperts, R.; Stratmann, R. E.; Yazyev, O.; Austin, A. J.; Cammi, R.; Pomelli, C.; Ochterski, J. W.; Ayala, P. Y.; Morokuma, M.; Voth, G. A.; Salvador, P.; Dannenberg, J. J.; Zakrzewski, V. G.; Dapprich, S.; Daniels, A. D.; Strain, M. C.; Farkas, O.; Malick, D. K.; Rabuck, A. D.; Raghavachari, K.; Foresman, J. B.; Ortiz, J. V.; Cui, Q.; Baboul, A. G.; Clifford, S.; Cioslowski, J.; Stefanov, B. B.; Liu, G.; Liashenko, A.; Piskorz, P.; Komaromi, I.; Martin, R. L.; Fox, D. J.; Keith, T.; Al-Laham, M. A.; Peng, C. Y.; Nanayakkara, A.; Challacombe, M.; Gill, P. M. W.; Johnson, B.; Chen, W.; Wong, M. W.; Gonzalez, C.; Pople, J. A. Gaussian 03, Revision C.02 Gaussian, Inc., Wallingford CT, 2004.

[20]. Foresman, J. B. in: Frisch, E. (Ed.), Exploring Chemistry with Electronic Structure Methods: A Guide to Using Gaussian, Pittsburg, PA 1996.

[21]. Wilson, E. B. Phys. Rev. 1934, 45, 706-714.

[22]. Roeges, N. P. G. A Guide to the Complete Interpretation of Infrared Spectra of Organic Structures, Wiley, New York, 1994.

[23]. Barthes, M.; De Nunzio, G.; Ribet, G. Synth. Met. 1996, 76, 337-340.

[24]. El-Asmy, A. A.; Al-Hazmi, G. A. A. Spectrochim. Acta 2009, 71A, 18851890.

[25]. Colthup, N. B.; Daly, L. H.; Wiberly, S. E. Introduction to Infrared and Raman Spectroscopy, third ed. Academic Press, Boston, MA, 1990.

[26]. Varsanyi, G. Assignments of Vibrational Spectra of Seven Hundred Benzene Derivatives, Wiley, New York, 1974.

[27]. El-Shahawy, A. S.; Ahmed, S. M.; Sayed, N. K. Spectrochim. Acta 2007, 66A, 143-152.

[28]. Panicker, C. Y.; Varghese, H. T.; Thansani, T. Turk. J. Chem. 2009, 33, 114.

[29]. Socrates, G. Infrared Characteristic Group Frequenceis, John Wiley and Sons, New York, 1980.

[30]. Nigam, S.; Patel, M. M.; Ray, A. J. Phys. Chem. Solids 2000, 61, 13891398.

[31]. Coates, J.; Meyers, R. A. Interpretation of Infrared Spectra, A Practical Approach, Chichester, John Wiley and Sons Ltd. 2000.

[32]. Harikumar, B; Varghese, H. T.; Panicker, C. Y.; Jayakumar, G. Spectrochim. Acta 2008, 71A, 731-738.
[33]. Panicker, C. Y.; Varghese, H. T.; Ambujakshan, K. R.; Mathew, S.; Ganguli, S.; Nanda, A. K.; Van Alsenoy, C.; Mary, Y. S. J. Mol. Struct. 2010, $963,137-144$

[34]. Colthup, N. B. Appl. Spectrosc. 1976, 30, 589-593.

[35]. Kuwae, A.; Machida, K. Spectrochim. Acta 1978, 34A, 785-791.

[36]. Higuchi, S.; Tsuyama, H.; Tanaka, S.; Kamada, H. Spectrochim. Acta 1974, 30A, 463-472.

[37]. Varsanyi, G.; Szoke, S. Vibrational Spectra of Benzene Derivatives, Academic Press, New York, London, 1969.

[38]. Sykes, P. K. Guide book to mechanism in organic chemistry, (6 $6^{\text {th }}$ edn), Pearson Education, New Delhi, India, 2004.

[39]. Dilovic, I.; Rubcic, M.; Vrdoljak, V.; Pavelic, S. K.; Kralj, M.; Piantanida, I.; Cindric, M. Bioorg. Med. Chem. 2008, 16, 5189-5198

[40]. Ramnathan, A.; Sivkumar, K.; Subramanian, K.; Janardhana, N.; Ramadas, K.; Fun, H. K. Acta Cryst. 1995, C51, 2446-2450.

[41]. Kleinman, D. A. Phys. Rev. 1962, 126, 1977-1979.

[42]. Adant, M.; Dupuis, I.; Bredas, L. Int. J. Quantum. Chem. 2004, 56, 497 507.

[43]. Koscien, E.; Sanetra, J.; Gondek, E.; Jarosz, B.; Kityk, I. V.; Ebothe, J.; Kityk, A. V. Spectrochim. Acta 2005, 61A, 1933-1938. 